\title{
Rising Sun in the Eastern Horizon of Java: The Occupation of Japanese 16th Army in Banyuwangi, East Java 1942-1945
}

\author{
Gema Budiarto ${ }^{1 *}$, Dewi Yuliati $^{1}$, and Dhanang Respati Puguh ${ }^{1}$ \\ ${ }^{1}$ Doctoral Program of History, Faculty of Humanities, Diponegoro University, Indonesia
}

\begin{abstract}
The Japanese Armed Forces did not take a long time to occupy the southern regions. Invading the southern regions was the Japanese's ambition to build "The Greater East Asia Co-Prosperity Sphere". Through Kalijati treaty, the Government of Dutch East Indies declared its unconditional surrender to the Japanese Armed Forces. Banyuwangi is an area located in the most eastern part of Java and considered as a strategic place as a defense fortress for all Java regions from the allied attacks from the south (Australia). The Japanese 16th Army implemented various policies as a part of the Greater East Asia War plan. The purpose of this study was to describe the policies made by the Japanese military government when occupying Banyuwangi, East Java. This study used a historical research method consisting of five steps: topic selection, heuristics, criticism, interpretation, and historiography. The result of this study shows that Banyuwangi is a strategic area where the Japanese 16th Army directly or indirectly implemented various policies for mass mobilization in supporting the Greater East Asia War. Through its propaganda, the Japanese military said that the Banyuwangi people's sacrifice was for a mutual victory in the war to build a new, safe, and prosperous Asia.
\end{abstract}

\section{Introduction}

Many people celebrated the Japanese victory by greeting the Japanese Army, assuming that Japan was the older brother of Indonesia. The Japanese Army entered Indonesia with a slogan nationalism, Pan-Asianism, Asia for Asia, defending Indonesia's honour, destroying western imperialism, etc. The song Heitai-san yo arigato! (Thank you, Mr Soldiers) was immediately sung by the people [1].

Before the Japanese Army occupied Indonesia, the Japanese bombers made the first threat in Banyuwangi on 21 February 1942. Approximately 13 bombs were dropped to attack Banyuwangi, in which 39 civilians were killed and 15 were injured [2][3][4][5]. The Japanese bombers dropped the bombs in Kampung Ujung and Sawahan. Many Banyuwangi people left their homes to save their lives. However, the Arab and China communities stayed at home because they did not want to leave their wares [6]. By the end of February

\footnotetext{
* Corresponding author: history.gema@gmail.com
} 
1942, the Japanese Armed Forces from Bali attempted to land in Banyuwangi, while the Dutch troops prepared the cannons along the coast of Java leading to the sea. The armoured and artillery brigades were also on standby all the time [7].

The arrival of the Japanese Army in Banyuwangi was also greeted since promising to bring the Banyuwangi people's needs, such as rice, corn, sugar, coffee, etc. Sri Adi Oetomo, in his book "Selayang pandang perang kemerdekaan di Bumi Blambangan [An Overview of Independence War in Blambangan]", stated that the arrival of the Japanese Army in Banyuwangi at the end of 1942 used a big ship with Hinomaru flag and anchored in the old Banyuwangi harbour (known as Boom today) [8]. His statement related to the arrival of the Japanese Army in Banyuwangi at the end of 1942 was wrong because, in the early March 1942, there was a battle between the Japanese Army and the Dutch troops in Banyuwangi [9] and on 6 March 1942, quoted a message from Tokyo broadcasted on Berlin radio saying that the Japanese Army occupied Banyuwangi in March [10-12]. Previously on 15 March 1942, Banyuwangi was besieged by the Japanese Army by entering Situbondo and Bondowoso through land route, while on 17 March 1942, by entering Banyuwangi through sea route [13].

According to [6], in his book "Enam Mata tentang Banyuwangi [Six Eyes about Banyuwangi]", explain that in Banyuwangi, the Japanese army was greeted by shouting "Banzai! Banzai! Dai Nippon! Dai Nippon!". The Japanese troops who were on top of the vehicle answered, "Indonesia! Hinomaru!". From the beginning of its arrival, the Japanese Army attempted to take the hearts of Banyuwangi people, especially Muslims, as the majority residents. When entering Banyuwangi, a vehicle brought five Japanese troops, which stopped in a Mosque, and three troops of the Japanese Army prayed two raka'ah [6]. It was unknown whether considered as true salah or just propaganda.

During the occupation, Banyuwangi regions were under the law of the Japanese 16th Army government implementing a military-political policy emphasizing Dai Tōa Sensō. A totalitarian system characterized by a dictatorship and controlling all state systems like the Japanese political actions to prevent the society in the occupied territories, including in Banyuwangi [14-15]. Based on the background above, this article will describe the policies issued by the Japanese 16th Army in the Banyuwangi regions to support Japan in the East Asian War.

\section{Social and Commodity Mobilization}

During its occupation, the cotton plant was one main commodity in Indonesia. The Japanese 16th Army strictly restricted the distribution of clothing materials yet developed the local cotton production on a massive scale. Due to these limitations and weak economic factors, the rural communities wore gunny sacks as their alternative everyday clothes. People only had a minimal number of clothes and were continuously worn since having no money to buy clothes. Therefore, gunny sack was used as alternative clothes although they were not comfortable to wear [16].

In the first occupation year, The Japanese 16th Army planned to build cotton productions until 1947. According to Jawa Menka Saibi Kyokai (The Cotton Planting Organization in Java), a good areas to plant cotton were Malang and Besuki [17]. One cotton planting area in Banyuwangi was Blambangan in Muncar Sub-District. Meanwhile, the cotton spinning and weaving activities were made in the people's homes and the products were used for themselves [18]. Aiko Kurasawa described the information; the cotton was only for family consumption needs. They sold the cotton when they needed money [17]. The cotton harvest was partially consumed, and the rest was handed over to Mitsui Norin [19]. The Japanese 16th Army government confirmed multiplying and expanding the cotton planting areas in vacant lands, such as house yards. This policy was to fulfil the people's needs related to clothing materials [20].

The food needs for the East Asia War required the people to send their rice to the 
Japanese 16th Army. Thus, the occupying government encouraged farmers to increase their rice production. The Banyuwangi people were also required to plant castor trees and tubers, such as badul and iles-iles [21]. Java Island has an essential role in supplying rice to Malaya, Singapore, and other places in war areas in the South Pacific regions. Although the rice production in Java was not as big as that in Thailand, Myanmar, and Cochinchina (the South of Vietnam), Java rice was known for its high quality and was preferred by the Japanese soldiers. In 1942, Shokuryo Kanri Zimusho (food management office) was formed under the Gunseikanbu Industrial Department.

In 1943, the rice market was banned, the yields were monitored, and the government carried out grinding \& distribution. Moreover, the occupying government also determined the rice quota that the farmers should fulfil and the rice purchasing price [17]. In Early 1944, Tonarigumi was formed and had the role in collecting the rice yields [22].

The Japanese 16th Army government ordered the village officials, such as the village heads (known as kucho), agriculture instructors (known as nogyo shidoin), Keibodan members, and Tonarigumi heads, also called kumicho, to oversee the entire rice handover processes [17]. The rice barns were searched, and the harvests were taken. The villagers did not dare to fight, yet surrendered because the Japanese occupying government brought soldiers [18]. Banyuwangi farmers were often confused in fulfilling the determined rice yields due to the absence of seeds and lacked male labourers [8].

In Banyuwangi, a rice grinding factory was built and called petuton. The reason why the Japanese occupying government built petuton was due to its inability to meet the demands. The petuton was built in Purwoharjo Sub-district and used lesung (a traditional rice processing instrument) in which the villagers called dolongan, while its activity was called nutoni [17]. Between April-October 1944, the rice provided by Kawedanan Banyuwangi was by $49.3 \%$, Kawedanan Rogojampi by $33.5 \%$, Kawedanan Blambangan by $78.8 \%$, and Kawedanan Bangorejo by $79.4 \%$. For the whole Banyuwangi Regency, the average rice provided by Karisedenan was $61.7 \%$ [17]. Rice was an important commodity, and, therefore, Banyuwangi residents were prohibited from bringing rice more than 2 kilograms on the train. If someone violated the rules, they would be caught by Kenpetai [6]. The Japanese military government in Besuki (including Banyuwangi) determined the prices of paddy (gabah), rice (beras), rice groats (menir), and rice bran (katul).

Table 1. The prices of rice (beras), rice groats (menir), and bran (katul).

\begin{tabular}{|l|l|l|l|l|}
\hline Type & $\begin{array}{l}\text { price on train } \\
\text { for wholesellers }\end{array}$ & $\begin{array}{l}\text { Price on train } \\
\text { for small traders }\end{array}$ & Retail price & Information \\
\hline Rice. & f 8.75 & $\mathrm{f} 9 .-$ & $\mathrm{f} 10 .-$ & $\begin{array}{l}\text { All sales were made } \\
\text { for each } 100 \\
\text { kg/sack. }\end{array}$ \\
$\begin{array}{l}\text { Glutinous rice } \\
\text { (beras ketan). }\end{array}$ & $\mathrm{f} 9.75$ & $\mathrm{f} 10 .-$ & $\mathrm{f} 11 .-$ & \\
\hline $\begin{array}{l}\text { Rice groats no. 1. } \\
\text { Rice groats no. 2. }\end{array}$ & $\begin{array}{l}\mathrm{f} 6.50 \\
\mathrm{f} 4 .-\end{array}$ & $\begin{array}{l}\mathrm{f} 6.75 \\
\mathrm{f} 4.25\end{array}$ & $\begin{array}{l}\mathrm{f} 7.50 \\
\mathrm{f} 5 .-\end{array}$ \\
\hline $\begin{array}{l}\text { Bran no. 1. } \\
\text { Bran no. 2. }\end{array}$ & - & - & $\mathrm{f} 2 .-$ \\
$\mathrm{f} 1.30$ & \\
\hline
\end{tabular}

Table 2. The paddy highest selling prices. 


\begin{tabular}{|l|l|}
\hline \multicolumn{1}{|c|}{ Type of Paddy } & \multicolumn{1}{c|}{ Received at factory } \\
\hline Bulu Paddy & f 4.30 \\
\hline Cere Paddy & f 3.90 \\
\hline Gagah Paddy & f 4.70 \\
\hline
\end{tabular}

Source: Makloemat No. 9, Tentang menetapkan harga pendjoealan jang paling tinge boeat padi, beras, beras-petjah (beras menir) dan dedak (katoel) [Information Number 9 on the Highest Established Purchasing Prices for Paddy, Rice, Rice Groats, and Rice Bran], Kan Po (No. 41, Tahun III, Bulan 4-2604/1942 [Number 41, Year III, Month 4-2604/1942]), p. 45-46.

The production development was intensified and affirmed by the Japanese 16th Army. Gunseikanbu stated that increasing food production was an important issue. Therefore the Gunseikanbu also took some actions to improve agriculture. Gunseikanbu mobilized villagers (especially farmers) to work very hard to increase the food yields [20].

Meanwhile, to fulfil the Banyuwangi people's needs, the government prohibited them from bringing the commodities out from Banyuwangi regions, such as batik cloth, sarong, coconut, copra, and pure coconut oil (minyak klentik). Those commodities could not leave Banyuwangi without legal permission from the Banyuwangi ken-tyoo, but this prohibition was not applicable for goods used by the Japanese Army. There was also a regulation stating that $50 \%$ of copra should be sold at predetermined prices in Banyuwangi for the coconut oil factory. Meanwhile, the other 50\% was allowed to sell elsewhere [23-24].

Louis Frederic described that Fujinkai was a women mobilization in war to help the soldiers [25]. Fujinkai was a women organization founded by the Japanese occupying government in August 1943. Fujinkai was also equipped with the basic military training tied to Seinendan and Keibodan. The background of its formation was to assist the Japanese war at the baseline by the position of women. Fujinkai was formed at the centre and in the regions to solve the socio-economic problems [26]. This organization was divided into two groups:

Aikoku fujinkai (Patriotic women's Association) and Kokubo fujinkai (National Defense Women's Association) as the most prominent organizations to mobilize and direct women's supports to the Japanese military establishment and communities in the 20th century... in February 1942, Aikoku Fujinkai and Kokubo Fujinkai were merged with the other national women's groups into Dai Nippon fujinkai (Greater Japan Women's Association) [27].

Fujinkai also had activity as labour in the agricultural fields. In several regions in Java, such as Banyuwangi, Fujinkai had to increase agricultural production. One Fujinkai unit known as Gerakan Gugur Bunga was a movement to mobilize women's labour to open new lands and cultivate those lands. The new lands were planted with food crops and others needed by people, including rice. In addition, Fujinkai in Banyuwangi made socks for the Japanese soldiers [28].

Many young men in Banyuwangi were recruited to become Keibodan and Seinendan. Keibodan was an additional police force [29] which members aged between 20-25 years old. Keibodan had the task of putting out the fires (especially the fires from bomb attacks) and encountering the allied aircraft attacks. Meanwhile, Seinendan recruited teenagers aged between 14-20 years old to help the public works, such as increasing agricultural or industrial production [30]. In addition, children who were still at school were recruited as members of Seinen Gakko [6].

It is undeniable that the pressures made by Japan resulted in a catastrophic famine so that the population suffered from malnutrition and reduced health conditions. People were encouraged to eat alternative foodstuffs, such as cassava, corn, and sweet potatoes [22]. In addition, the banana tree stump, papaya leaf, and cassava leaf were also used as food. For protein fulfilment, it was recommended to eat snails. 
The misery of the Banyuwangi people over the Japanese military occupation was told in a song called genjer-genjer [31]. This song was created by Muhammad Arif, a composer from Banyuwangi. Genjer-genjer song had a social theme. Unfortunately, this song was considered controversial because some groups judged that this song belonged to a banned party in Indonesia (The Communist Party of Indonesia).

\section{Defense and Security Policies}

Banyuwangi was the Banyuwangi was the Japanese 16th Army strategic place as its fortress to maintain Java from the allied attacks. The distance between Banyuwangi and Darwin (the base of an allied army), Australia, was approximately $1.860 \mathrm{~km}$. Therefore, it would take a few days to reach Banyuwangi by ships. Besides, Banyuwangi had a strategic place since the Banyuwangi social communities were far from Surabaya, the capital city of East Java. Therefore, the Dutch did not significantly influence the Banyuwangi people, and the arrival of the Japanese Army in Banyuwangi could be easily accepted [21].

As explained above, the early arrival of the Japanese Armed Forces in Banyuwangi brought several things needed by the people, yet evidently, the Japanese Armed Forces ships anchored in Banyuwangi brought the armaments [21]. After occupying Banyuwangi, the Japanese Army, through romusha built a fortress and bunker in the eastern and southern coastal areas of Banyuwangi. The Japanese 16th Army recruited some local people and exploited their workforce for romusha. The men recruited for romusha were sent to the working areas, such as Watu Dodol, Gumuk Kantong, Sembulungan, Grajagan, Kalipait (the slopes of Mount Nistho near Alas Purwo), Lampon (Today, the military area for the Indonesian Marine Corps), Rowoputih, Poncomoyo, Pulau Merah (Red Island), Sukamade, and Sarongan/Rajegwesi.

The labour mobilization also utilized the villagers around the bunker while the system was made in one village for one working week [32]. In addition, the romusha members in Banyuwangi were also sent to other countries, such as Malaysia (Malaya), Myanmar (Burma), and Thailand, to work and build bunkers and railways. The romusha members lived under heavy pressures and miserable conditions provided with very few facilities. The health problems or tortures experienced by the romusha members were the common pictures of what happened at that time so that many romusha members died at their workplaces. Nevertheless, the Japanese military government remained in its stance. It continuously exploited the romusha members to work for the prosperity of Greater East Asia, which was safe, prosperous, and free from Western colonialism [8].

Banyuwangi also had two daidans (battalions) of PETA. The first daidan was located in Southern Banyuwangi in Benculuk Sub-district, while Srono Sub-district was used as the kenpetai HQ. The second daidan was located in Banyuwangi city, taking over the Dutch building (the local people called it Inggrisan). In contrast, the north of this building was used as the kenpetai HQ [33][6]. To maintain and control the security in the society, the Japanese Army formed the main police office (Keisatu-syo).

Banyuwangi had three Keisatu-syo established by Gunseikanbu consisting of Stadspolitie Banyuwangi, Veldpolitie Banyuwangi, and Veldpolitie Genteng [34]. During the Japanese occupation, not all places in Banyuwangi could be used by the civilians, such as the Boom Harbor. The civilians were forbidden from entering this area. The Boom Meneng Bridge was guarded by the Japanese Army, mentioning that anyone trying to enter the area would be punished [6]. The Boom was a landing area for Japanese troops. Thus, it can be concluded that there was military equipment in this area not to be known by the outsiders or civilians.

The Japanese Army also forbade all assemblies in East Java, including Banyuwangi. Those who would gather should report and obtain permission from the regional offices. The report should include the gathering aims and objectives, date, place, members, and nonpolitical movement [35]. In East Java, the meeting between P. T. Rioe (Head of afd. P. I. D. 
East Java), P. T. Takahara (advisor/ interpreter), and Soedjono (Head of P. I. D. Surabaya) emphasized on the Regulation No. 23 to dismiss all organizations [36].

The success of the Japanese Army in political control, including defence and security, could not be separated from the role of Japanese spies in Java before the war. There was a Cino kelontong (Chinese retailer) term that traded and sold clothes. People called them Cino or Chinese because the traders had slanted eyes and fair skin, yet they were not Chinese but Japanese. Cino kelontong was thought to be the Japanese spy or intelligent part of the Japanese Army who had the task to oversee the details of village areas [37]. In Kebaman, Srono Sub-district there lived a Japanese person usually called Tuan Yamani. He was a trader who lived in the area since the Dutch era and still in Indonesia or before the Japanese military entered. People said that Tuan Yamani was a member of the Japanese Army because after Japan lost the war, he returned to his country and disappeared. Tuan Yamani might have been intelligence from the Japanese Army. The opinion that Tuan Yamani was a soldier or Tuan Yamani was a merchant who deliberately helped succeed in the Japanese mission to spy the area was not completely correct.

As explained by Ken'Ichi Goto related to the Japanese spy, the overview of Java was not only performed in the main or big cities. Intensive monitoring was also thoroughly performed in the remote cities located in the inland of Java [38]. Sosa Taneji, an Ex-Rear Admiral of the Imperial Japanese Navy, viewed that the Japanese small businessmen were more respectable than the big Japanese businessmen in the Dutch East Indies. Taneji thought that the small Japanese businessmen had built their trades from small and considered the Dutch East Indies their home. Yet, these small businessmen eventually had a major role in the Japanese expansion [38].

The return of Japanese soldiers from the occupied territories was explained by Sakari Ono [39]. The AFNEI (Allied Forces Netherlands East Indies), commanded by Rear Admiral W.R. Patterson, The commander of the British V Exploration Squadron, aimed at disarming and returning the Japanese soldiers to Japan. Although most Japanese soldiers had returned to Japan, Sakari Ono and a few Japanese troops chose to remain in Indonesia and decided to join the Indonesian Army [40].

Another thing performed during wartime to maintain stability was constructing the internment camps to detain the threatening groups. The formation of internment camps aimed to oversee and minimize the resistance movement. In the internment camps, many prisoners died due to several factors, such as illness, fatigue due to forced labour, or accidentally being killed.

In Banyuwangi, the Japanese military also established the internment camps, as explained by Frances Worthington Lipe, showing that in some places, the internment camps were built, such as in Banyuwangi city (temporary camps for special prisoners from the military who were later transferred to the military camps in Surabaya), Blambangan in Muncar Sub-district, Srono and Kesilir which were included in the Surabaya Civil Camp Areas [41]. Lieutenant General Imamura Hitoshi expected that the Kesilir area could be the internment camp for 70,000 European and Eurasian prisoners, including men, women, and children [42].

The camp area was Kesilir and included the Sanggar (Pesanggaran) area [42]. In July and August 1942, about 2,000 Dutch and 1,000 Eurasians were brought to Kesilir, yet put in the separated barracks [43]. The internment camps were not new buildings. Those camps were the houses of residents evicted by the Japanese soldiers and reused as the camps [21]. The Japanese occupying government did not cover the life necessities of the prisoners. Therefore they had to support themselves [42].

\section{Conclusion}

The Japanese occupation in Banyuwangi emphasized three main aspects: social and commodity mobilization, defence and security policies, and the educational system. In its 
mobilization efforts, the Japanese army applied total mobilization by exploiting the natural resources and social aspects. The mobilization of natural resources was highly prioritized by the Japanese army in Banyuwangi, emphasizing the production of cotton, rice, and other food and clothing needs. Meanwhile, the organizations made by the Japanese army in Banyuwangi, such as Fujinkai, Keibodan, Seinendan, and Seinen Gakko played an important role in supporting the war. However, they were only in the baseline.

Banyuwangi was a strategic area as the defence fortress in Java. Therefore, the Japanese army used romusha to build a bunker along the east and south coasts to oversee the movements of the allied troops from the south (Australia). Banyuwangi had two daidans of PETA and three major police stations in Banyuwangi. There were also several concentration camps in Banyuwangi, and one of them was Kesilir internment camp for the civilian prisoners of the allied countries.

\section{References}

1. S. Melati, Di Bawah Penjajahan Bendera Matahari [Under the colonization of the Sun Flag], in Radikalisme Lokal: Oposisi dan Perlawanan Terhadap Pendudukan Jepang di Jawa (1942-1945) [Local Radicalism: Opposition and Fight against Japanese Colonialism in Java (1942-1945)], Antariksa; Candra Utama, Ed. Yogyakarta: Syarikat Indonesia (2012)

2. “Attack on Java", Kalgoorlie Miner, 3 (1942)

3. "Island Key of N. E. I.," Examiner, 1, (1942)

4. "Enemy Destroyers Sunk," Daily Advertiser, 1, (Feb, 1942)

5. "39 Killed at Banjowangi," Recorder, 1 (1942)

6. H. Singodimayan, H. Basri, A. Jusuf, Enam Mata tentang Banyuwangi [Six Eyes on Banyuwangi], Pustaka Larasan Denpasar (2015)

7. “Java's Mobile Power," The Sun, 3 (1942)

8. S. A. Oetomo, Selayang Pandang Perang Kemerdekaan di Bumi Blambangan [An Overview about the Independence War in Blambangan Kingdom], Garoeda Buana Indah Pasuruan (1996)

9. “The Java Battle Scene," The Sun, 5 (1942)

10. “Banjoewangi Taken," Cairns Post, 5 (1942)

11. “Capture of Batavia," Kalgoorlie Miner, 5 (1942)

12. “Japs. Pincer Movement Threatens Batavia Dutch Determined Despite Big Odds, "The Telegraph, 1 (Mar, 1942)

13. "Ports Darwin, Moresby Are Again Bombed", The Tribune, 4 (1942)

14. C. Z. Friedrich, Z. Brzezinski, The General Characteristics of Totalitarian Dictatorship, in Comparative Government, Jean Blondel, Palgrave Macmillan Ed. London (1969)

15. C. A. Ridgewell, The 'Popular' Concept of Totalitarianism, Simon Fraser University (1970)

16. Interview with Mr. Sungkono (2017)

17. A. Kurasawa, Kuasa Jepang di Jawa: Perubahan Sosial di Pedesaan 1942-1945 [Japan's Authority in Java: Social Changes in Villages between 1942-1945], Komunitas Bambu Depok (2015)

18. Interview with Mrs. Suyinah (2017)

19. "Mitsui norin is the corporation that assists the cotton farmer by supplying seeds, buying, packing and shipping. Mitsui norin holds up several areas such as Besuki, 
Jakarta, Cirebon, Pekalongan, Semarang, Pati, Bojonegoro, Surabaya, and Madura. Meanwhile"

20. Lampiran 4 [Appendix 4], Memperbanjak Hasil Produksi Dimasa Peperangan [Increasing the Production Yields during the Wartime], Kan Po, 9- 10 (Nov, 1943)

21. H. Muryantoro, Banyuwangi: Situasi dan Kondisi Politik, Sosial, Ekonomi, Budaya dan Militer pada Masa Pendudukan Jepang (1942-1945) [Banyuwangi: Political, Social, Economic, Cultural, and Military Situations and Conditions during the Japanese Accupation], Patrawidya, 13(2), 229-247 (2012)

22. A. Kurasawa, Masyarakat dan Perang Asia Timur Raya: sejarah dengan foto yang tak terceritakan [Society and the Great East Asian War: History with Untold Photographs], Komunitas Bambu Depok (2016)

23. Larangan membawa keloear barang dagangan [Prohibition to Bring Commodities outside the Region], Kan Po, 19 (Oct, 1942)

24. Atoeran oentoek Banjowangi Ken, tentang pengeloearan boeah kelapa, kopra, dan minjak kelapa [Regulation for Banyuwangi on Excluding Coconuts, Copra, and Coconut Oils from the Region], Kan Po, 19-20 (Oct, 1942)

25. L. Frederic, Japan Encyclopedia, Cambridge: Harvard University Press (2002)

26. M. D. Poesponegoro, N. Notosusanto, Sejarah Nasional Indonesia VI "Zaman Jepang dan Zaman Republik [Indonesian National History in "Japanese Era and Republic Era], Balai Pustaka Jakarta (2009)

27. L. G. Perez, Japan at War "An Encyclopedia”, ABC-CLIO California (2013)

28. S. Fatimah, Fujinkai (Women's Association), in The Encyclopedia of Indonesia in the Pacific War, Peter Post., Brill Leiden (2010)

29. Indrus, S. U. Nababan, Two Stories of the Japanese Occupation, Indonesia, 2, 125134 (1966)

30. Wiretno, E. B. Santoso, Kediri-Syuu Masa Pendudukan Jepang: Pengaruh Kebijakan Pemerintah Militer Jepang Terhadap Kehidupan Sosial Tahun 1942-1945 [KediriSyuu during the Japanese Occupation: the Influence of Japanese Military Government Policies on the Social Life in 1942-1945], J. Kesejarahan, 10(1), 23-35 (2017)

31. U. Parlindungan, Mitos Genjer-Genjer: Politik Makna dalam Lagu [Genjer-genjer Myth: Politics of Meaning in the Song], J. Ilmu Sos. dan Ilmu Polit., 17(3), 236-253 (2014)

32. Interview with Mrs. Novi (Head of Section 2 of the Alas Purwo National Park), Banyuwangi (2021)

33. S. Sato, "The Peta," in The Encyclopedia of Indonesia in the Pacific War (Peter Post, William H. Frederick, Iris Heidebrink, Shigeru Sato, S. S. Peter Post, William H. Frederick, Iris Heidebrink, Ed. Leiden: Brill, 2010.

34. "Nama, tempat dan daerah kekoeasaan Keisatu-syo (Kantor Besar Polisi) di Djawa ditşetapkan oleh Dai Nippon Gun Gunseikan (Pembesar pemerintah balatentara Dai Nippon) dalam belan 8 jang laloe [Name, Place, and Region Authorized by Keisatusyo in Java Established by Dai Nippon Gun Gunseikan in the Last $8^{\text {th }}$ Month]," Kan Po, p. 9, Sep. 1942.

35. "Oendang-oendang No. 23 tentang mentjaboet sebahagian larangan bersidang dan berkoempoel [Law No. 23 on Revoking some assembling and gathering prohibitions]," Kan Po, pp. 5-6, Aug. 1942.

36. Larangan bersidang dan berkoempoel, semoea perkoempoelan haroes diboebarkan [Prohibition to assembly and gather, all organizations Must be Dismissed], Kan Po, 41 (Aug, 1942) 
37. Interview with Mr. Sungkono and Mr. Maladi, Banyuwangi (2017)

38. K. Goto, Jepang dan Pergerakan Kebangsaan Indonesia [Japan and Indonesian Nationality Movement], Yayasan Obor Indonesia Jakarta (1998)

39. "Sakari Ono or Rahmat Shigeru Ono was the former Japanese army who settled in Blitar, Indonesia."

40. E. Hayashi, Memoar Rahmat Shigeru Ono: Bekas Tentara Jepang yang Memihak Republik [], Ombak Publisher Yogyakarta (2011)

41. F. W. Lipe, Japanese Prisoner of War Camps During World War II, 1941-1945: Knowns Location of Camps where America, British, Dutch, Australian, Canadian, India, and other Allied Military and Civilian Personnel were imprisoned by the Japanese, Medical Research Committee of American Ex-Prisoners of War Inc Texas (1980)

42. J. G. Wackwitz, Kesilir July 1942-September 1943 Rapport van de leider der Kolonisatie, 's-Gravenhage (1988)

43. I. Heidebrink, The Eurasian Community During The Japanese Occupation, 19421945, in The Encyclopedia of Indonesia in the Pacific War, S. S. Peter Post, William H. Frederick, Iris Heidebrink, Ed. Leiden: Brill (2010) 